\title{
Eodinia poulseni sp. nov., a dinoflagellate cyst from Middle Jurassic of Central Poland
}

\author{
MARCIN BARSKI \\ Geology Department, University of Warsaw, 93 Zwirki i Wigury Str., 02- 089 Warsaw, Poland (e-mail: marbar@geo.uw.edu.pl).
}

\begin{abstract}
A new species of dinoflagellate, Eodinia poulseni, is described from the Middle Jurassic of Central Poland. Light and scaning electron microscopy shows that this species has a complex cyst wall consisting of autophragm and ectophragm. Eodinia poulseni sp. nov. has similarities to some common Middle Jurassic species, especially when separate hypocysts are observed. Important differences between Eodinia pachytheca, Mosaicodinium mosaicum, Wanaea acollaris, W. cornucavata and Hurlandsia rugarum are discussed. Some phylogenetic and environmental relationships to the Early Cretaceous freshwater species Hurlandsia rugarum are suggested. H. rugarum shows similarity in archaeopyle, overall shape and tabulation formula but is acavate and also distinct from E. poulseni in time. J. Micropalaeontol. 21(1): 43-49, May 2002.
\end{abstract}

\section{INTRODUCTION}

During a palynological study of core samples from five boreholes in the Kujawy region of Central Poland (Figs 1 and 2) a rich dinoflagellate cyst assemblage was recovered (Fig. 3) including a new species of Eodinia Eisenack, 1936. It is present in large numbers in all the boreholes analysed. The new species, named Eodinia poulseni, occurs within zone DSJ 15 (early-mid Bathonian) and DSJ 16 (mid-late Bathonian) of the dinoflagellate zonation for central Poland (Poulsen, 1998).

The study area is situated in the central part of the Mid-Polish Trough. This region was a part of the European Jurassic epicontinental basin close to the East-European Platform margin. The sedimentological setting and the palynofacies analysis also suggests a proximal position to the platform. The lithologies of the cores studied mostly consist of sandstones, clays and sandstones with clayey intercalations. The area was uplifted in Middle Jurassic times during a halokinetic phase. The uplift phase caused several synsedimentological erosional periods which created a number of facies differences.

Samples were prepared according to standard palynological techniques following Poulsen et al. (1990). Holotype, paratypes and type material are lodged in the Museum of the Geology Department of the University of Warsaw.

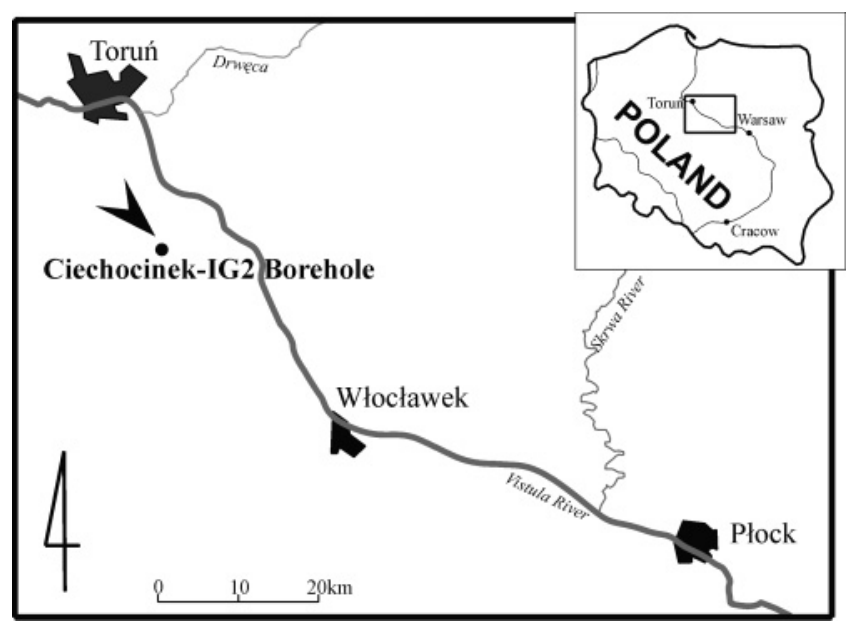

Fig. 1. Map showing holotype locality.

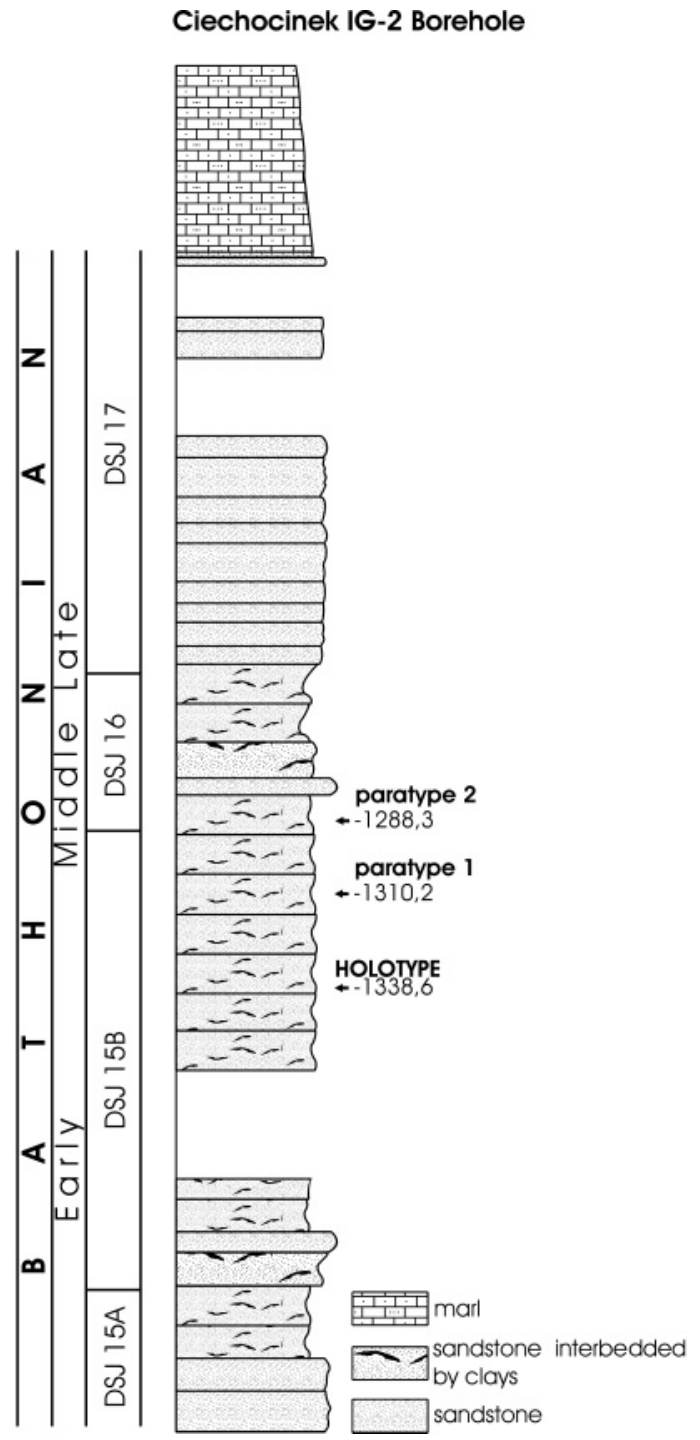

Fig. 2. Section of the Ciechocinek IG-2 borehole and its stratigraphic position, with reference to the dinoflagellate cyst zonation of Poulsen (1998). 
M. Barski

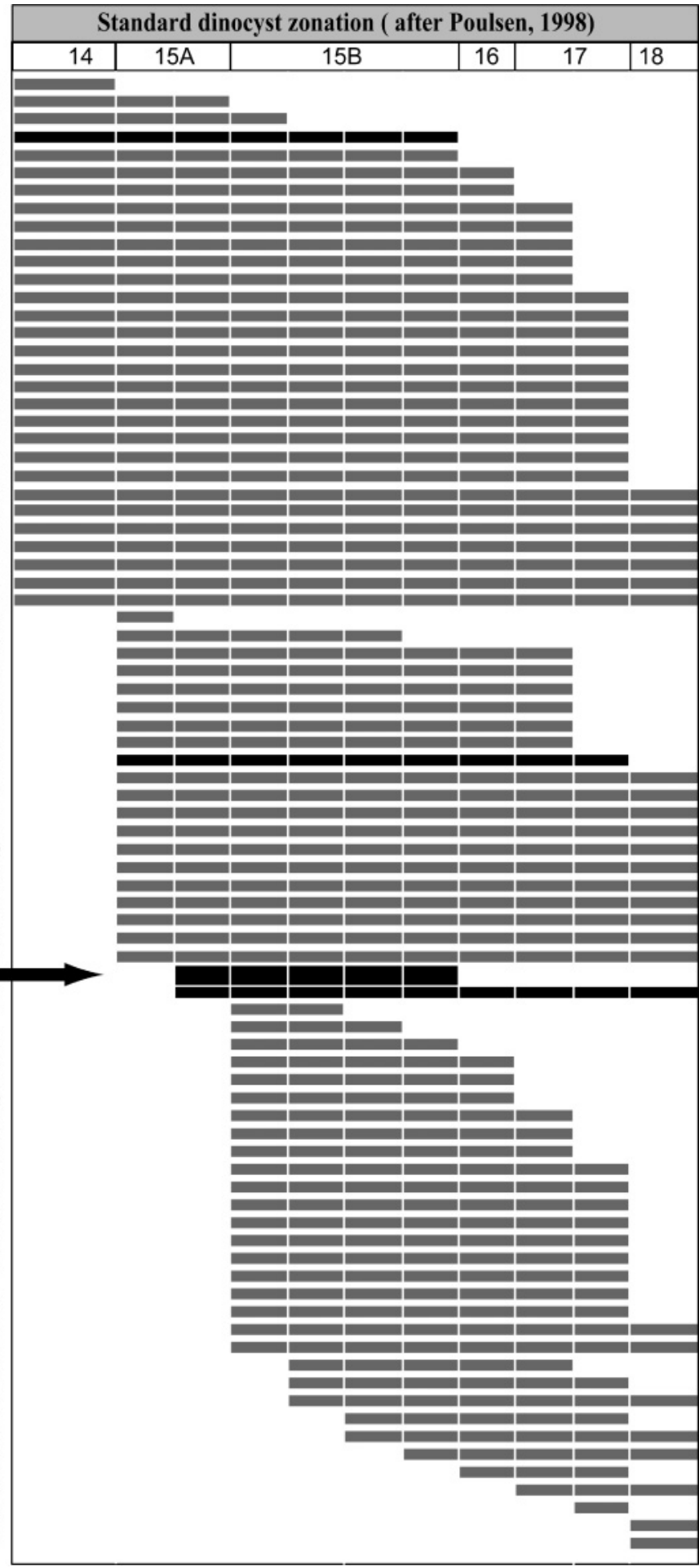

Fig. 3. Stratigraphic range of Eodinia poulseni sp. nov. compared to other dinoflagellates.

allosphaeridium capulatum Lithodinia valensti

Dapsitidimina deflandrei

Kallosphaeridium praussii

crinium asymmetricum

Kallosphaeridium hypornatum Dissiliodinium willei

Korystocysta pachyderm a

Atopodinium haromense

Sentusiainium villersense

Ctenidodinium combazil

Dichadogonyaulax sellwoodi

Epiplosphaera reticulat

Aldorfia aldorfensis

Korystocysta gochti.

Nannoceratopsis gracilis

Pilosidinium echinatum

Pilosidinium fensomei
Valensiella ovuld

Ellipsoidictyum cinctum

Epiplosphaera gochti

Onyaulacysta jurassica adecta

Barbatacysta brevispinosa

Valensiella ampulla

Dissiliodinium caddaense

?Heslertonia pellueida

Barbatacysta peltrida

Crenidodinium cornigera

Dissiliodinium hocneranim

Endoserinium galeritum

Tubotuberella dangeardii

Valensiella vermiculata

Barbatacys

Chlamydophorella nyei

Cometodinium jurassicum

Ctenidodinium continutum

Escharisphaeridia psilata

Lithodinia callomoni

Lithodinia caytonensis

Lithodinia jurassica

Lithodinia jurassica

Lithodimia reticulata

Eodinia poulseni

Mosaicodinium mosaicum

Carpathodinium predae

Omatidium sp.

Atopodinium polygonalis

Escharisphaeridia mantell

Surculosphaeridium cribrotubiferum

Lithodinia bulloided

Tubotuberella apateld

Chvtroeispheridia chytroeides

?Rhynchodiniopsis regatis

Adnatosphoridium is regalis

Hapsidaulax margarethe

Impletosphaeridium ehrenbergii Kalyptea stegasta

Rigaudella filamentoso

Sentusidinium riousa

Sentusidinitum rioultii

Nannoceratopsis pellucida

Valvaeodinium spinosum

Epiplosphaera bireticulata

Impletosphaeridium tribuliferum Rigandella aemula

Systematophora penicillata

hynchodiniopsis cladophora

Gonyaulacysta eisenackit

Epiplosphaera areolata

Systematophora areolate 

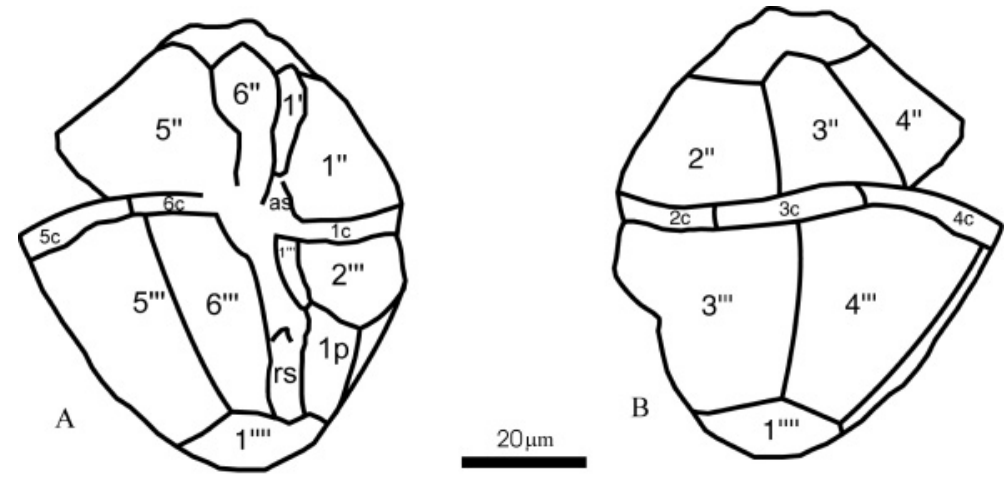

Fig. 4. The reconstructed tabulation formula of Eodinia poulseni on (a) ventral and (b) dorsal sides of the cyst.

SYSTEMATIC DESCRIPTION

Division Dinoflagellata (Butschli 1885) Fensome et al., 1993

Subdivision Dinokaryota Fensome et al., 1993

Class Dinophycae Pascher, 1914

Order Gonyaulacales Taylor, 1980

Suborder Gonyaulacineae Norris, 1978 (autonym)

Family Gonyaulacaceae Lindemann, 1928

Subfamily Leptodinioideae Fensome et al., 1993

Genus Eodinia Eisenack, 1936 emend. Gocht, 1975 emend. Berger, 1986

Remarks. Emendations of the genus Eodinia Eisenack, 1936 by Gocht (1975) and Berger (1986) described the wall structure and provided details of the endophragm and periphragm. However, Stover \& Evitt (1978), in a modified generic description, correctly described both the auto-and ectophragm. Mosaicodinium Dodekova, 1990, seems to be closely related but differs from Eodinia Eisenack, 1936 by the presence of an antapical paraplate which is inclined and elongate (Dodekova, 1975). In contrast, the genus Eodinia is characterized by a symmetrical, antapical paraplate (Gocht, 1975).

\section{Eodinia poulseni sp. nov.}

(Pl. 1, figs 1-6)

Derivation of name. Eodinia poulseni is named after Dr Niels Erik Poulsen (Geological Survey of Denmark and Greenland), the author's first teacher in Jurassic dinoflagellate cysts.

Shape. Polygonal with a conical hypocyst and flat epicyst where a small apical protrusion is formed by the ectophragm.

Wall relationship. Cyst holocavate. Autophragm and ectophragm are developed uniformly around the whole cyst.

Wall features. Autophragm smooth to scabrate. Ectophragm continuous, smooth and transparent. The two layers are connected by solid pillars.

Paratabulation. The complete tabulation pattern is difficult to recognise in light microscopy. In SEM a gonyaulacacean sexiform type tabulation is reflected with tabulation formula: ?', $6^{\prime \prime}, 6 \mathrm{c}, 6^{\prime \prime \prime}, 1 \mathrm{p}, 1^{\prime \prime \prime \prime}$ (Fig. 4). The antapical paraplate is symmetrical.

Archaeopyle. Epicystal. Operculum attached ventrally.

Paracingulum. Indicated by transverse parallel ridges.

Parasulcus. Indicated by a depression on the hypocyst.

Size. Intermediate, see 'Dimensions'.

Holotype. Plate 1 (fig. 1). Slide C2/103. Co-ordinates: $\mathrm{X}=300, \mathrm{Y}=1118$ (upper right corner $\mathrm{X}=001, \mathrm{Y}=0007$ ). Holotype is lodged at the University of Warsaw in the Museum of the Geology Department under catalogue number IGPUW/Df/01/ 001a. Locality: Ciechocinek IG-2 Borehole, depth $-1338.6 \mathrm{~m}$ (Fig. 2), Central Poland, Kujawy region.

Paratype 1. Plate 1 (fig. 3). Slide C2/103. Co-ordinates: $\mathrm{X}=322, \mathrm{Y}=1416$ (upper right corner $\mathrm{X}=001, \mathrm{Y}=0007$ ). Ciechocinek IG-2 Borehole, depth $-1338.6 \mathrm{~m}$ (Fig. 2). Cat. No. IGPUW/Df/01/001b.

Paratype 2. Plate 1 (fig. 4). Slide C2/74. Co-ordinates: $\mathrm{X}=280, \mathrm{Y}=1215$ (upper right corner $\mathrm{X}=001, \mathrm{Y}=0007$ ). Ciechocinek IG-2 Borehole, depth $-1310.2 \mathrm{~m}$ (Fig. 2). Cat. No. IGPUW/Df/01/002.

Description. Isolated, conical hypocysts are typical. The autophragm/ectophragm relationship is clearly seen on the edges of the hypocyst. In the epicyst a small apical protrusion is occasionally discernible. In the hypocysts, the pillar connections are evident in apical view (P1. 1, fig. 6). Dark-coloured cysts usually show a scabrate autophragm. Common folds on cyst surface blur the tabulation pattern. Under SEM a gonyaulacacean type tabulation is reflected by low, narrow ridges $(\mathrm{Pl}$. 2, figs 1, 2). The antapical paraplate was only seen in a few specimens. It is symmetrical, gonyaulacacean-sexiform type (P1. 1, fig. 5). In the SEM micrographs of the hypocsts, some trichocyst pores (Pl. 2, fig. 4) are weakly expressed (Gocht, 1975). 

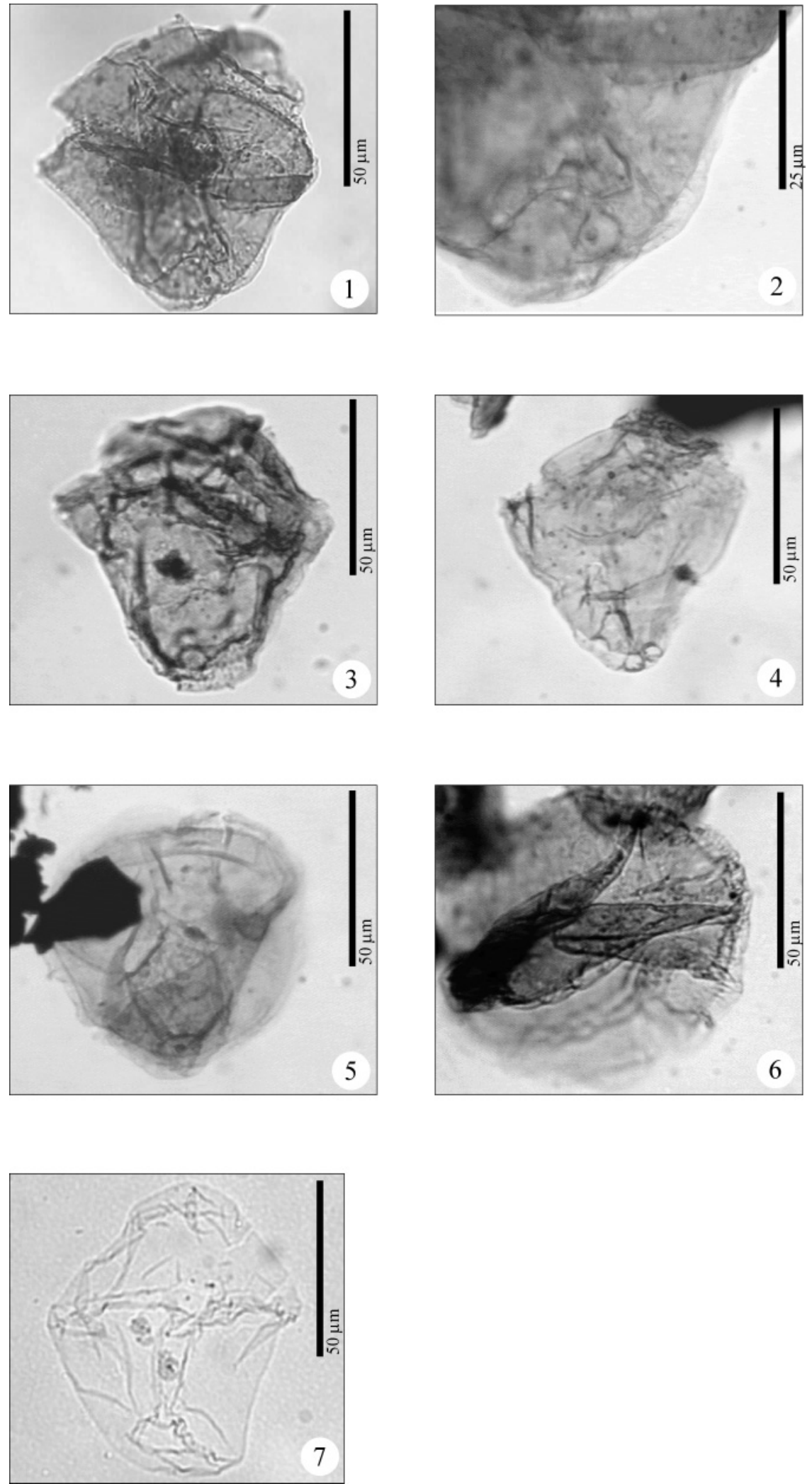

Explanation of Plate 1

Figs 1-6. Eodinia poulseni sp. nov.: 1, holotype; 2, holotype at higher magnification, showing the endophragm/periphragm wall relationship; $\mathbf{3}$, paratype $1 ; \mathbf{4}$, paratype $2 ; \mathbf{5}$, antapical view, showing normal, symmetrical antapical (1' $\left.1^{\prime \prime \prime}\right)$ paraplate; $\mathbf{6}$, antapical view, illustrating the similarity to Wanaea acollaris in this position. Fig. 7. Hurlandsia rugarum (Piasecki, 1984) Lister \& Batten, 1988; holotype. 

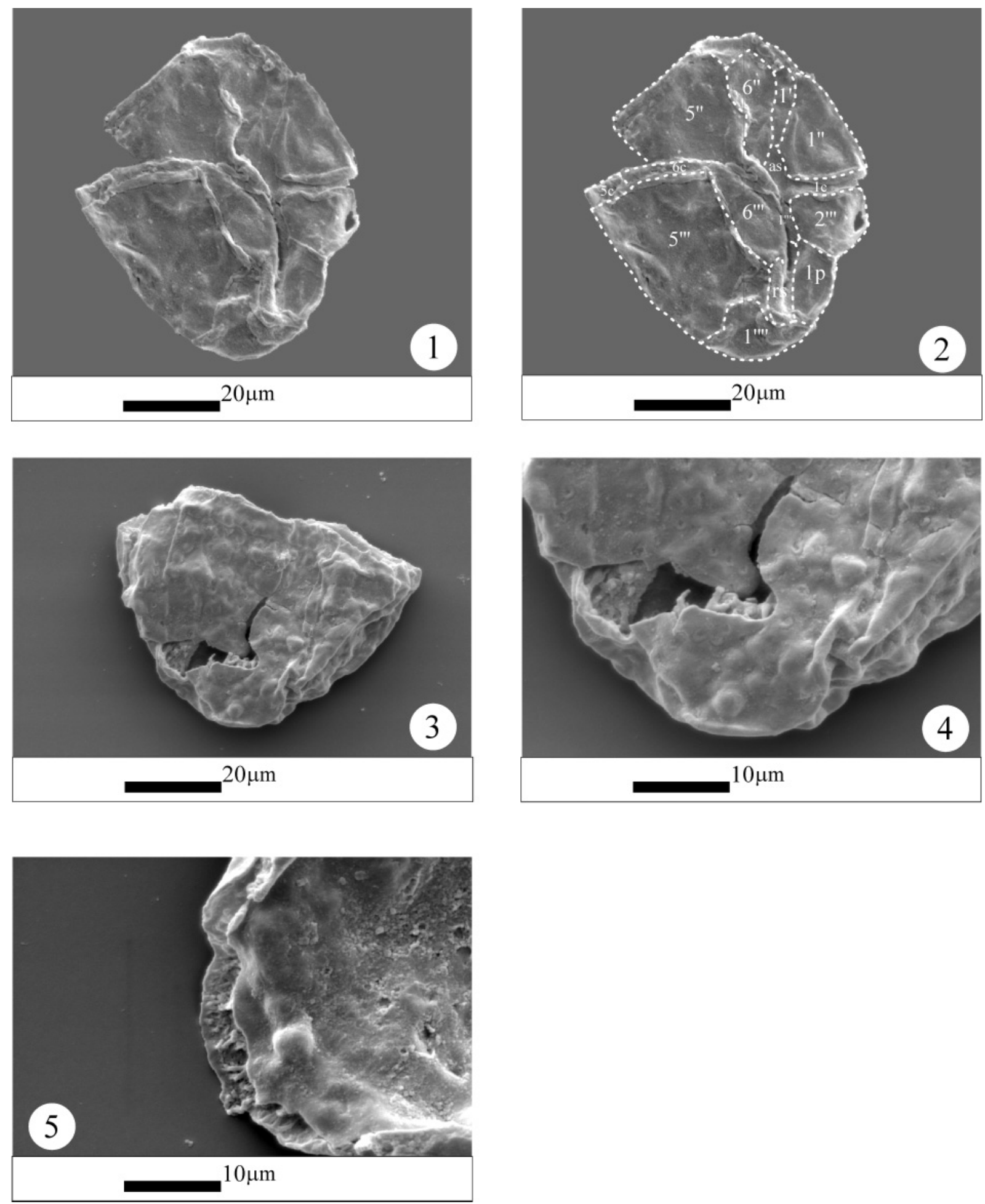

Explanation of Plate 2

Figs 1-5. Eodinia poulseni sp. nov.: 1, 2, complete specimen in SEM and partial tabulation formula interpretation; 3-5, SEM photomicrographs showing the internal pillar structures between wall layers. 


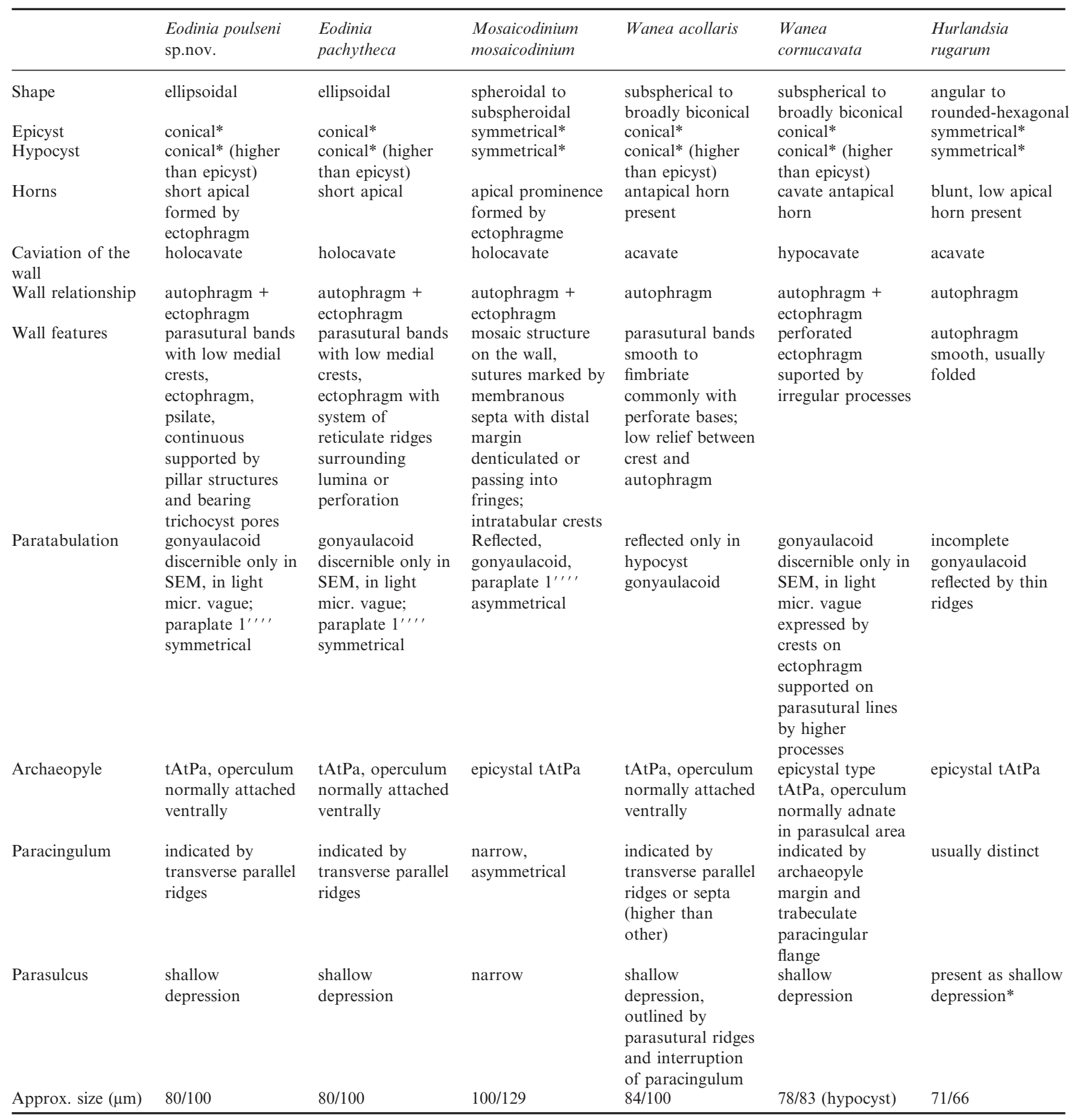

*Author's interpretation.

Table 1. Comparison of the important morphological features of the species that may be confused with Eodinia poulseni sp. nov.

Dimensions. Whole cyst: holotype height: $82 \mu \mathrm{m}$, width $91 \mu \mathrm{m}$. Hypocysts (based on 23 specimens; maximum/mean/minimum): height: 74/60/49 $\mu \mathrm{m}$, width: 93/77/55 $\mu \mathrm{m}$.

Comparison and remarks. Within holocavate cysts, Eodinia poulseni differs from Mosaicodinium mosaicum Dodekova, 1975 and Eodinia pachytheca Eisenack, 1936 by having a psilate to shagreenate, continuous ectophragm. The two latter species are characterized by a mosaic and reticulate outer layer

Recorded occurrence. Zones DSJ 15 (early-mid Bathonian) and DSJ 16 (mid-late Bathonian). ornamentation, respectively. In apical view, Eodinia poulseni 
resembles Wanaea acollaris. The pillars between the wall layers in Eodinia poulseni in this position are very similar in appearance to fringe-like structures surrounding the cingulum in Wanaea acollaris (P1. 1, fig. 6). However, Wanaea acollaris can be distinguished by an antapical horn and is also acavate. In contrast, in Wanaea cornucavata Feist-Burkhard \& Pross, 1998 the cavate antapical horn is fully developed.

The Early Cretaceous species Hurlandsia rugarum Lister \& Batten, 1988 (Pl. 1, fig. 7), shows clear similarities in overall shape, archaeopyle and tabulation type to Eodinia poulseni. They can be differentiated only by their wall structure. Hurlandsia rugarum is acavate, whereas Eodinia poulseni is holocavate.

Lister \& Batten (1988) suggested that Hurlandsia rugarum is probably the product of a freshwater dinoflagellate. The reduction in wall number may be due either to environmental factors or phylogenetic reasons. This point should be considered in the future study of both Jurassic and Cretaceous material.

The most important morphological features of the species discussed above are compared in Table 1.

\section{ACKNOWLEDGEMENTS}

This study is a part of a $\mathrm{PhD}$ project financially supported by University of Warsaw, the State Committee for Scientific Research and the Danish Rectors Conference which funded a four month scholarship in Denmark. The author is indebted to Dr Niels Poulsen of the Geological Survey of Denmark and Greenland for his invaluable assistance.

\section{Manuscript received 12 September 2000 \\ Manuscript accepted 22 January 2002}

\section{REFERENCES}

Berger, J.P. 1986. Dinoflagellates of the Callovian-Oxfordian boundary of the 'Liesber- Dorf' quarry (Berner Jura, Switzerland). Neues Jahrbuch für Geologie und Paläontologie, Abhandlungen, 172: 331355.

Dodekova, L. 1975. New Upper Bathonian dinoflagellate cysts from north-eastern Bulgaria. Bulgarian Academy of Sciences, Palaentology, Stratigraphy and Lithology, 2: 17-34.

Gocht, H. 1975. Neuuntersuchung von Eodinia pachytheca Eisenack, 1936 (Dinoflagellata, Oberjura). Neues Jahrbuch für Geologie und Paläontologie, Abhandlungen, 148: 12-32.

Lister, J.K. \& Batten, D.J. 1988. Hurlandsia, a new non-marine Early Cretaceous dinocyst genus. Neues Jahrbuch für Geologie und Paläontologie, Monatshefte, 8: 505-516.

Poulsen, N.E., Gudmundsson, L., Hansen, J.M. \& Husfeld, Y. 1990. Palynological preparation techniques, a new Maceration tankmethod and other modification. Geological Survey of Denmark series C., 10.

Poulsen, N.E. 1998. Bajocian to Callovian (Jurassic) dinoflagellate cysts from central Poland. Acta Geologica Polonica, 48: 237-245.

Stover, L. \& Evitt, W.R. 1978. Analyses of pre-Pleistocene organicwalled dinoflagellates. Stanford University Publications, Geological Sciences, 15: 1-300. 